\title{
Microbial contamination in food, food- handlers' hands and surfaces and evaluation of contamination sources by the similarity between isolates
}

\author{
Metin ERDOĞAN ${ }^{1, a}$, Șebnem PAMUK ${ }^{2, b, 凹}$ \\ ${ }^{1}$ AfyonKocatepe University, Faculty of Veterinary Medicine, Department of Medical Biology and Genetics; ${ }^{2}$ Department of Food \\ Hygiene and Technology, Afyonkarahisar, Turkey. \\ ${ }^{\mathrm{a} O R C I D: ~ 0000-0003-0975-1989 ; ~}{ }^{\mathrm{b} O R C I D: 0000-0001-7227-3364}$

${ }$ Corresponding author: spamuk @ aku.edu.tr
Received date: $31.07 .2019-$ Accepted date: 28.10 .2019

\begin{abstract}
Food can be contaminated with surfaces and food employees during chopping, shredding and serving. Pathogenic microorganisms are transmitted by direct contact with food or indirectly with airborne particles. The aim of this study was to determine the prevalence and the relationship between pathogenic microorganisms isolated from food, kitchen equipment and foodhandler's hands. A total of 212 microbiological samples were collected from surfaces, foods and food handlers' hands at different six canteens inside of the Afyon Kocatepe University campus during the period 2017-2018. Following biochemical tests, identification of Staphylococcus species were performed from a specific region of 23S rRNA gene. The genetic relationships between totally 25 Staphylococcus spp. and Proteus mirabilis isolates were determined. S.epidermidis was detected in two samples from knife handle (5\%), nine samples from hands $(20 \%)$ and in one of food sample (1\%), too. S.aureus was found to be existed in one sample from hands (2.2\%), two samples of soujouk (2\%) and in one sample pancakes (3\%) obtained from the university canteens. Besides from one of food sample (1\%) S.sciuri, from one of hand sample (2.2\%) S.haemolyticus and one of the food samples (1\%) S. saprophyticus bacteria were identified. As a result, foods, food preparation surfaces and foodhandler's hands were contaminated with microorganisms in canteens and they were similar/same to each other. Also, considering the number of isolates, the highest of contamination is the hands of food-handler.
\end{abstract}

Keywords: Canteen, contamination, food, genotyping, sequence analysis.

\section{Gıdalarda, gıda çalışanlarının ellerinde ve yüzeylerde mikrobiyal kontaminasyon ve kontaminasyon kaynaklarının izolatlar arasındaki benzerlikler ile değerlendirilmesi}

Özet: Gıdalar işleme, hazırlama, doğrama, parçalama ve servis sırasında yüzeyler ya da gıda çalışanları aracıllığıyla kontamine olabilmektedir. Patojen mikroorganizmalar gıdaya doğrudan temas veya dolaylı olarak havadaki partiküller ile bulaşmaktadır. Bu çalışmanın amacı, gıda, mutfak ekipmanları ve gıda çalışanlarının ellerinden izole edilen patojen mikroorganizmaların prevalansını ve aralarındaki ilişkiyi belirlemektir. Afyon Kocatepe Üniversitesi kampüsünde yer alan altı farklı kantinden 2017-2018 döneminde yüzeylerden, gıda ve gıda çalışanlarının ellerinden toplam 212 örnek toplandı. Staphylococcus spp. identifikasyonu biyokimyasal testlerin akabinde 23S rRNA geninin belirli bir bölgesi baz alınarak gerçekleştirildi. Toplam 25 Staphylococcus spp. ve Proteus mirabilis izolatı arasındaki genetik ilişki belirlendi. İki bıçak sapından (\%5), dokuz elden (\%20) ve bir gıdadan (\%1) S. epidermidis tespit edildi. S. aureus bir el (\%2,2), iki sucuk (\%2) ve bir gıda (gözleme) örneğinde (\%3) bulundu. Ayrıca, bir gida örneğinde (\%1) $S$. sciuri ve $S$. saprophyticus, bir el örneğinde ise $(\% 2,2)$ S. haemolyticus saptandı. Sonuç olarak, kantinlerdeki gıdaların, hazırlama yüzeyleri ve çalışan ellerinin mikroorganizmalar ile kontamine olduğu ve bu mikroorganizmaların birbirleriyle aynı/benzer yapıda oldukları saptandı. Ayrıca, izolat sayıları dikkate alındığında, en yüksek kontaminasyonun gıda çalışan ellerine ait olduğu tespit edildi.

Anahtar sözcükler: DNA dizi analizi, genotiplendirme, gıda, kantin, kontaminasyon.

\section{Introduction}

Food safety is one of the most important perspectives in foodservice operations. However, this issue is generally accepted as the smallest amount of observation and attention (38). Many interrelated determinants are effecting microbial contamination of foods related to the preparation method, the hygienic sanitary situation of catering/canteen facilities, or food handling, storage, and distribution $(14,42)$. The unsuitable handling of foods by the food service sector has been a major concern in $97 \%$ of food poisoning cases (17, 36). Pathogenic microorganisms are spreading through the foodhandlers' hands and lead to cross-contamination (1, 33). Staphylococcus aureus is one of the leading causes of food 
poisoning by means of enterotoxins (20). This commensal and opportunistic pathogen that is the main resident in humans, is mostly isolated from the nostrils, skin, oropharynx and feces $(6,23)$. Therefore, human-induced contamination the third most important cause of foodborne diseases in the world (28). Food poisoning has been stated to be a result of infection with enterotoxigenic strains of S. aureus and occurred to be $14-20 \%$ of outbreaks involving contaminated food (9). Today, Coagulase Negative Staphylococcus (CoNS), as general opportunist, reflects one of the major nosocomial pathogens, having a significant effect on human life and health. These microorganisms are found in different parts of the skin and mucous membranes of the host. $S$. epidermidis colonizes the body surface, predominantly existing in moist areas, such as the axillae, inguinal and perineal areas, anterior nares, conjunctiva, and toe webs. S. haemolyticus is primarily isolated from axillae and pubic areas, which are high in apocrine glands. $S$. saprophyticus mostly exists in the rectum and genitourinary tract $(4,31)$. S. sciuri is known as an invasive pathogen for wound infections, blood, urine and abscesses in humans. Also, the agent is commonly found in a large variety of hosts and environments and frequent contact with pets and livestock has been stated to cause skin colonization and wounds $(16,37)$. Also, dust is an important tool in the transport of these bacteria $(25,27)$.

The Enterobacteriaceae group of bacteria is the most challenging bacterial contaminant to raw and processed meat products worldwide (3). Proteus mirabilis, a member of this group is known to be other human opportunistic pathogens, isolated from urine, wounds, and other clinical sources. Intestine is the reservoir of such proteolytic microorganisms. A lot of wild and domestic animals are hosts of Proteus spp., which are mostly known to play a role of parasites or commensals. Proteus spp., generally present in soil or water habitats is usually considered as indicators of faecal pollution, creating a threat of poisoning when the contaminated water or food is consumed (12). According to our best knowledge, an extensive evaluation of a sequence-based PCR method for the identification from different sources of Staphylococcus spp. and Enterobacteriaceae has not been reported in the literature.
This study aims to detect microorganisms important for food safety and public health from foods, surfaces and hands of employees and to determine the relationship between cross-contamination and sources of contamination between these isolates.

\section{Material and Methods}

This study was performed with the permission of the Afyon Kocatepe University Animal Ethics Committee (2016-49533702-68).

Microbiological sampling of surfaces, food equipment, and food handler's hands: A total of 212 microbiological samples of surfaces, food tools and food handler's hands were taken different six canteens inside the university campus during the period 2017-2018.

One hundred gram of food samples were taken to sterile bags and brought to the laboratory under the cold chain and analyzed within 1-2 hours. Ten grams of each food samples were taken aseptically, transferred to sterile plastic bags and homogenized with $90 \mathrm{~mL}$ of sterile peptone water $(1 \mathrm{~g} / \mathrm{L})$ for 60 seconds. After the serial dilutions of the samples, they were inoculated in growth media using standard drop-plate method (Table 1).

There were six canteens in the university with 45 food handlers (inclusive of permanent and contract workers). Hand samples were taken from thumb and forefinger through the "press your finger into the petri dishes" method. For this purpose, RODAC petri dishes containing Baird-Parker Agar (Oxoid, CM 0275, Basingstoke, UK) and Chromocult Coliform Agar (Merck 1.10426 , Germany) were used and incubated at $37^{\circ} \mathrm{C}$ for $24 \mathrm{~h}$. In a sampling of food-contact surfaces (27 cutting board, 40 knives handle) was carried out by using a sterile frame of $15 \mathrm{~cm}^{2}$ that was used to outline a known area, inside which the swabbing was done. The swab was then placed in a tube containing $10 \mathrm{~mL}$ of maximum recovery dilution with $0.05 \%$ sodium thiosulfate (MRD, Oxoid CM733, Basingstoke, UK) and stored in an ice container and then analyzed within $2 \mathrm{~h}$. The Enterobacteriaceae and Staphylococcus spp., counts were obtained after incubation on Chromocult Coliform Agar and BairdParker Agar at $37^{\circ} \mathrm{C}$ for 24 h. Enterobacteriaceae and Staphylococcus spp. were determined by biochemical and coagulase tests $(5,7,10)$.

Table 1. Culture media, plating techniques and incubation conditions.

\begin{tabular}{|c|c|c|c|c|}
\hline \multirow{2}{*}{ Microorganisms } & \multicolumn{2}{|c|}{ Incubation } & \multirow{2}{*}{ Culture technique } & \multirow{2}{*}{ Culture media and confirmation tests } \\
\hline & Time (h) & Temperature $\left({ }^{\circ} \mathrm{C}\right)$ & & \\
\hline Staphylococcus spp. & 24 & 37 & Drop plate & $\begin{array}{l}\text { Baird-Parker Agar plus egg yolk tellurite } \\
\text { emulsion }(5 \% \text { v/v) (Oxoid CM 0275). } \\
\text { Black colonies, Gram positive }\end{array}$ \\
\hline Enterobacteriaceae & 24 & 37 & Drop plate & $\begin{array}{l}\text { Chromocult Coliform Agar (Merck, } \\
\text { 1.10426). Colorless typical colonies }\end{array}$ \\
\hline
\end{tabular}




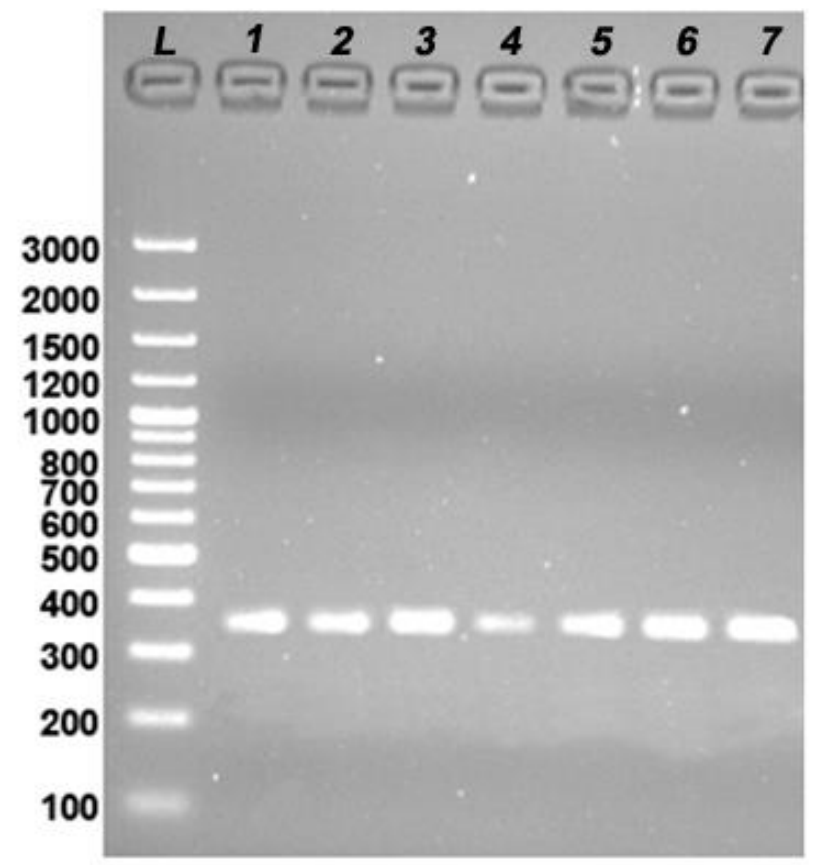

Figure 1. PCR fragment size of bacterial species in samples.Lanes: M, GeneRuler 100 bp Plus DNA Ladder (ThermoFisher Scientific, SM0323, USA); Lane 1, Positive control; Lane 2, Sample A; Lane 3, Sample 6; Lane 4, Sample 30; Lane 5, Sample 43; Lane 6, Sample 54, Lane 7, Sample 67.

Polymerase Chain Reaction and sequencing: Briefly, the total genomic DNA was isolated by using the commercial spin column kit (Thermo Fisher Scientific, K0722, USA) according to the manufacturer's instructions. Primers were designed using the Fast PCR Professional 6.1.2 package program (21). The dimer and hairpin formation between the primers were controlled by the same program. Isolated DNA was amplified using the forward primer: F112 (5'-TTC CGA ATG GGG AAA CCC AGC-3') and reverse primer R472 (5'-GCC TTA GGA GAT GGT CCT CCC A-3'). It was 23S rRNA genes in order to evaluate Staphylococcus spp. and Enterobacteriaceae strains. The gradient PCR was previously performed to determine the melting temperature $\left(\mathrm{T}_{\mathrm{m}}\right)$. Totally, $20 \mu$ l containing $1 \mathrm{xPCR}$ buffer, $2.5 \mathrm{mM} \mathrm{MgCl}_{2}, 0.2 \mathrm{mM} \mathrm{dNTP}, 0.25 \mathrm{mM}$ forward and reverse primers, $1 \mathrm{U}$ Platinium Taq DNA polymerase (Invitrogen, 10966034, USA) and 20 ng template DNA were included into PCR reactions performed in a thermocycler (Applied Biosystems Veriti). The PCR protocol was set to initial denaturation at $95^{\circ} \mathrm{C}$ for $2 \mathrm{~min}$, 35 cycles of denaturation $30 \mathrm{sec}$ at $94^{\circ} \mathrm{C}, 30 \mathrm{sec}$ primer annealing at $60^{\circ} \mathrm{C}, 1 \mathrm{~min}$ extension at $72^{\circ} \mathrm{C}$ and, a final extension at $72^{\circ} \mathrm{C}$ for $10 \mathrm{~min}$., respectively. Amplification products were analyzed by gel electrophoresis on $2 \%$ agarose gel (Figure 1) followed by RedSafe (INtRON, 21141, South Korea) staining. Subsequently, all of the PCR products were purged with Exonuclease I (Thermo Fisher Scientific, EN0581, USA) and FastAP
Thermosensitive Alkaline Phosphatase (Thermo Fisher Scientific, EF0652, USA).

Sequencing PCR was performed according to BigDyeTherminator 3.1 kit protocol. The products obtained at the end of the sequenced PCR were purified by ethanol / EDTA / sodium acetate precipitation method. HiDi formamide was added to $15 \mu$ to each well and loaded onto the DNA Sequence Analyzer (ABI 3500).

Statistical analyses: All sequences were edited (GeneCode, Sequencher 5.4.6), aligned with the BioEdit Sequence Alignment Editor Analysis Program (18) and amplification product was read $360 \mathrm{bp}$. Genotypic results were compared and similarity searches were performed using MEGA 4. (40).

\section{Results}

Sequence analysis of the $23 \mathrm{~S}$ rRNA, a highly conserved region present in all bacteria, has been implemented in laboratories to identify CoNS species. All analysis of Staphylococcus spp. and Enterobacteriaceae strains were performed using one primer set and generated PCR products were 360 bp in size. Most of strains revealed visually same fingerprint profiles (Table 2). The relationship between isolates are shown on the dendrogram (Figure 2). The present study determined the genetic relationships between 19 Staphyloccocus spp. and 6 P. mirabilis isolates obtained from food, food handlers' hand and food equipment by genotyping characterization. For this purpose, Staphylococcus spp. and P. mirabilis genes were evaluated by sequence analysis.

Most isolates were harvested from hands $(52 \%)$ and food samples $(36 \%)$ while few isolates (12\%) were obtained from kitchen equipment. Sequence analysis revealed a correlation between some strains and the source of the isolates. In our study, the prevalence of food pathogens were determined in foods, hands and kitchen equipment. According to this; $P$. mirabilis was isolated from three samples of food (3\%), one sample of hands $(2.2 \%)$ and one sample of knife handle $(2.5 \%)$, also $S$. aureus was isolated one sample of hands (2.2\%), two of soujouk samples and one of the pancakes $(3 \%)$ in the university canteens. Besides, S. epidermidis has been detected from two of knife handle samples (5\%), nine of hand samples $(20 \%)$ and one of the food sample (1\%) (chicken skewers). Also, from one of the food sample (1\%) S. sciuri, from one sample of hand (2.2\%) S. haemolyticus and from one of food samples (1\%) $S$. saprophyticus were isolated. According to these results this; S. aureus isolates existed from food handlers' hand and soujouk, also S. epidermidis isolates obtained from knife handle and foodhandlers' hands were revealed $100 \%$ similar in blast comparison in $1^{\text {st }}$ canteen. Correlatively, $S$. epidermidis isolates obtained from food handlers' hands and chicken skewers have been identified as $100 \%$ similar 
Table 2. Identification of 25 food, food handler's and food contact surface isolates by using DNA sequencing.

\begin{tabular}{|c|c|c|c|c|}
\hline Sample (Source) & Similarity $100 \%$ & GenBank No (26) & Definitive Identification & $\begin{array}{l}\text { Canteen } \\
\text { Number }\end{array}$ \\
\hline A (KnifeHandle) & S. epidermidis strain CDC121 & $\begin{array}{l}\text { CР034115.1 } \\
\end{array}$ & S. epidermidis & Canteen 1 \\
\hline 9 (Hand) & S. epidermidis strain $\mathrm{CDC} 121$ & $\mathrm{CP} 034115.1$ & S. epidermidis & Canteen 1 \\
\hline 41 (KnifeHandle) & S. epidermidis strain $\mathrm{CDC} 121$ & $\mathrm{CP} 034115.1$ & S. epidermidis & Canteen 1 \\
\hline 43 (Hand) & S. aureus strain PCFH-226 & CP035005.1 & S. aureus & Canteen 1 \\
\hline 52 (Soujouk) & S. aureus strain PCFH-226/ FORC-061 & CP035005.1 & S. aureus & Canteen 1 \\
\hline 6 (Hand) & S. epidermidis strain NCTC4133 & LR134242.1 & S. epidermidis & Canteen 2 \\
\hline 8 (Hand) & S. epidermidis strain CDC121 & $\mathrm{CP} 034115.1$ & S. epidermidis & Canteen 3 \\
\hline 47 (Hand) & P. mirabilis strain NCTC4199 & LR134205.1 & P. mirabilis & Canteen 4 \\
\hline 13 (Hand) & S. epidermidis strain $\mathrm{CDC} 121$ & $\mathrm{CP} 034115.1$ & S. epidermidis & Canteen 4 \\
\hline 14 (Hand) & S. epidermidis strain CDC121 & СР034115.1 & S. epidermidis & Canteen 5 \\
\hline 19 (Hand) & S. epidermidis strain $\mathrm{CDC} 121$ & СР034115.1 & S. epidermidis & Canteen 6 \\
\hline 18 (Hand) & S. epidermidis strain $\mathrm{CDC} 121$ & СР034115.1 & S. epidermidis & Canteen 6 \\
\hline 20 (Hand) & S. epidermidis strain CDC 121 & CP034115.1 & S. epidermidis & Canteen 6 \\
\hline 30 (Hand) & S. haemolyticus strain SGAir0252 & СР025031.1 & S. haemolyticus & Canteen 6 \\
\hline 31 (Hand) & S. epidermidis strain CDC121 & CP034115.1 & S. epidermidis & Canteen 6 \\
\hline 42 (Hand) & S. epidermidis strain CDC121 & CP034115.1 & S. epidermidis & Canteen 6 \\
\hline 54 (Vegetable mix) & S. sciuri strain NCTC12103 & LS483305.1 & S. sciuri & Canteen 6 \\
\hline 61 (Chickenskewers) & S. epidermidis strain CDC121 & СР034115.1 & S. epidermidis & Canteen 6 \\
\hline 63 (Pancakes) & S. aureus strain PCFH-226 & СР035005.1 & S. aureus & Canteen 6 \\
\hline 67 (Urfa Kebab) & S. saprophyticus strain NCTC7666 & LR134089.1 & S. saprophyticus & Canteen 6 \\
\hline 58 (Adana Kebab) & P. mirabilis strain NCTC4199 & LR134205.1 & P. mirabilis & Canteen 6 \\
\hline 60 (Adana Kebab) & P. mirabilis strain NCTC4199 & LR134205.1 & P. mirabilis & Canteen 6 \\
\hline 46 (Hand) & P. mirabilis strain NCTC4199 & LR134205.1 & P. mirabilis & Canteen 6 \\
\hline 38 (KnifeHandle) & P. mirabilis strain NCTC4199 & LR134205.1 & P. mirabilis & Canteen 6 \\
\hline 66 (Meatball) & P. mirabilis strain NCTC4199 & LR134205.1 & P. mirabilis & Canteen 6 \\
\hline
\end{tabular}

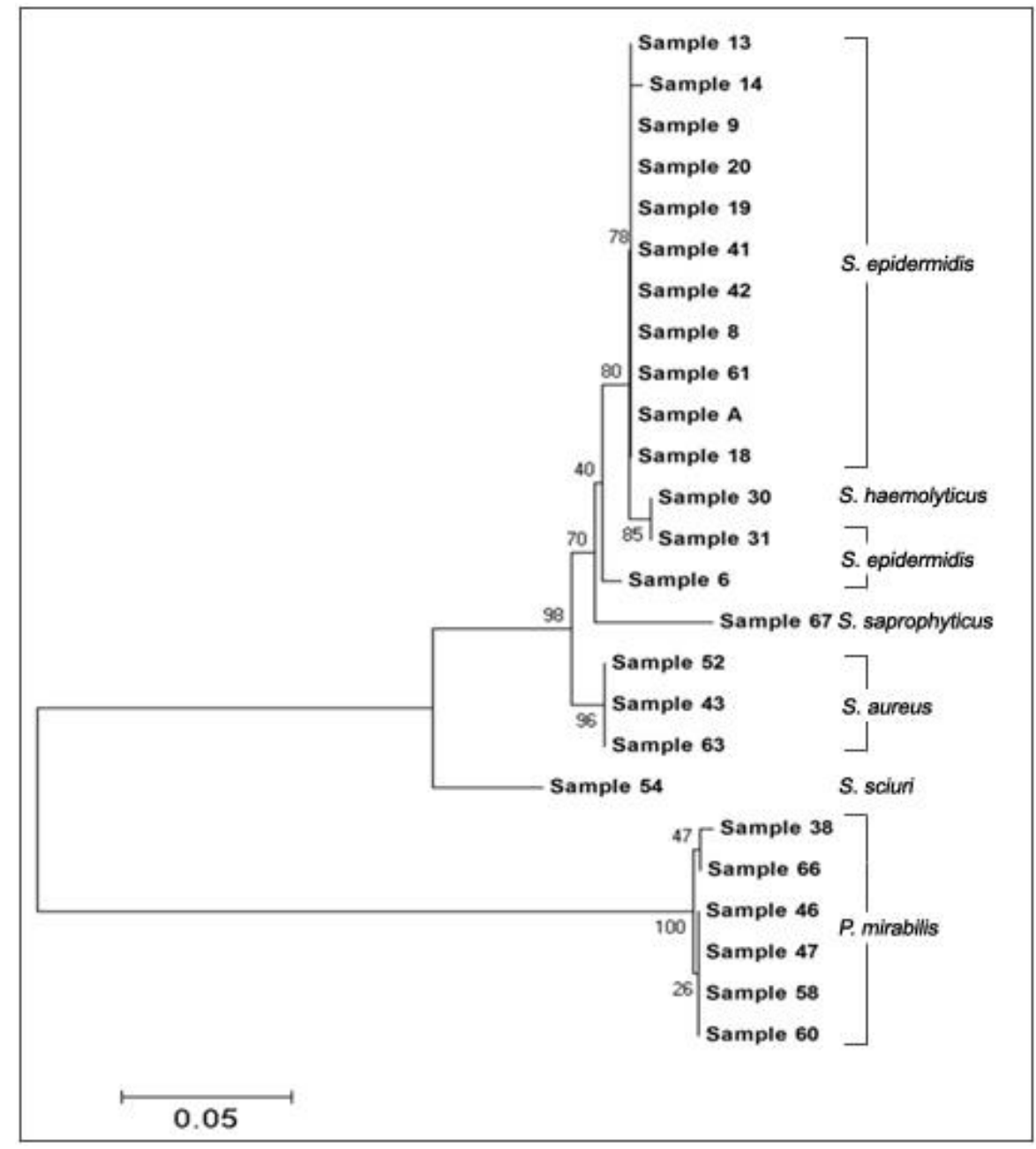

Figure 2. The relationship between isolates with dendrogram. 
isolates in the number $6^{\text {th }}$ canteen, also coagulase negative staphylococci such as $S$. haemolyticus, S. sciuri, $S$. saprophyticus found in human skin and mucosa were identified in foods. In the same canteen, $100 \%$ similar $P$. mirabilis isolates were determined from food, food handlers' hands and knife handles. In $2^{\text {nd }}, 3^{\text {rd }}, 4^{\text {th }}$ and $5^{\text {th }}$ canteens, $P$. mirabilis and $S$. epidermidis isolates were found to be the same as those obtained from other canteens. As shown in the dendrogram, bootstrap values are generally high $(78,96,98$ etc.) and reliable, some values are low $(26,40$, etc.). This is because; sample 6 , for example, although $S$. epidermidis isolates, the other $S$. epidermidis is similar to $40 \%$ due to differences in 13 different nucleotides. Samples 38, 66 and 46, 47, 58, 60, identified as $P$. mirabilis are $100 \%$ similar, although they are separated from each other in terms of two nucleotides. However, 38 and 66 P. mirabilis isolates are 20-47\% similar to other Staphylococcus spp. isolates.

The Neighbor-Joining method was opted to deduct the evolutionary relationship of isolates (32). The optimal tree with the sum of branch length $=0.46534862$ is shown in Figure 2. The branches designate the percentage of replicates of acquainted taxa clusters obtained during bootstrap test (1000 replicates) (15). To develop the phylogenetic tree same units of branch lengths were used as those of evolutionary distances when drawing to the scale. The evolutionary distances were calculated by following the Maximum Composite Likelihood method and the number of base substitutions per site was used as units (41). All positions from data set were cleared by using complete deletion option for prevalent gaps and absent values. A total of 297 positions in the final dataset were obtained. Phylogenetic assessments were performed in MEGA 4 (40).

\section{Discussion and Conclusion}

In this study, food samples consisted of ready-to-eat and freshly prepared foods. The food contact with equipment harboring pathogens contributed as a most significant factor during a processing of food. Another reason which was among the leading cause of food contamination were the peeling trimming, slicing, milling, shredding, mechanical abrasion and diverse disintegration processes which could bring pollutants from related equipment $(24,34)$. Especially, the contaminated cutting boards used during cutting of raw meat, and poultry etc. when coming in contact with other foods, are among the major sources of contamination (44). The infected food handlers and their non-hygienic applications during food processing and preparation contribute another to contamination (19). Human (skins and nostrils, mucosae's and cuts, open wounds, or an infected wound) can function as major reservoirs of pathogens, such as $S$. aureus and Proteus spp., and act as vectors and contaminated food under hygienic conditions, especially unwashed hands (8, 13, 39). The results of following study clearly outline the reasons for food contamination with E. coli, Klebsiella and Citrobacter which are likely in a food service setting and food handlers' hands. It is possible that different populations of employees in different localities and during different times of the year could carry variable hand carriage rates for vulnerable pathogenic species and more frequently infects the surfaces or foods (11). In another study using various products containing 238 retail samples, 137 samples of intact and raw vegetables, and 159 samples of fresh products were analyzed for different microorganisms and researchers were able to isolate $S$. aureus from two samples of raw vegetables and five kinds of cooked foods (22). S. aureus (16\%) and Proteus spp. (12\%) was detected from 55 analyzed food samples (39), P. mirabilis (6.3\%), S. aureus (3.2\%) from 252 samples (24), from 12 samples Proteus spp. (22.7\%) were significant and accompanied by $S$. aureus (13.6\%) (29), in 48 ready to eat foods and chicken derivative products $S$. aureus was the predominant organisms with $30 \%$ and Proteus spp. (12\%) (30). Wang et al. (43), showed that the handlers and helpers of cook in the kitchen and waiters were among the sources who carried infectious agents, and he described that pork balls were contaminated with Proteus spp. Also, a confirmation was recorded that the waiter and cook handler had previously contacted the pork balls directly without washing hands $4 \mathrm{~h}$ before the dinner. Although studies are generally related to food, no similar study has been found to determine the relationship between the isolates obtained from food, hands and food contact surfaces. According to our results; the same or similar isolates determined from food, food surfaces and food handlers' hand indicate that there is cross contamination in the same canteen (26). In this study, workers in contact with food are seasonal, part-time, rotated and some of them are citizens of different countries. Studies suggest that with the help of microbial indicators, it is easy to pinpoint the inadequacy in the food quality $(35,42)$. The practices such as the habit of touching contaminated surface while wearing gloves, the phenomenon of sneezing or coughing into a gloved hand, exclusive habit of not wearing gloves are major sources of food contamination other than actual contamination during food processing and preparation. Generally, the food handlers who lack the habit of wearing gloves usually escalate Staph bacteria to food (13). Besides, roughly $71.4 \%$ of food handlers had not known $S$. aureus is the causative agent of foodborne infections (2). The information obtained from this study is a strong evidence of the presence of cross-contamination of personnel and inadequate hygiene practices at mass consumption sites as well as it may be used to formulate the necessary measures to protect against foodborne infections and intoxications. 
In order to maintain and assure the availability of good quality meals and foods for students, strict and comprehensive regulations notified by the authorities must be followed by catering services. Despite the fact that food safety legislation do exist, yet the administration of the school, cafeteria and canteen during meal preparation fails to justify the food safety needs and sometimes even does not take into account the specific hygienic requirements needed for each stage of food preparation. Consequently, during the whole production chain, food is constantly exposed to microbial contamination. The genotypic results of the present study may help to better understand the distribution of microorganisms between food, food handler and food contact surfaces and provide information on foodborne infection pathways.

As a consequence, food handlers should have basic understanding and a good attitude about personal hygiene, hand washing and proper cleaning and strict food hygiene practices. Health hazards associated with catering facilities can be nullified by avoiding poor handling. Similarly, self-consciousness about personal hygiene and safeties during food preparation and storage could help to combat foodborne diseases. Periodic sanitary-hygienic evaluation, proper monitoring of catering facilities and strict quality control of food should be enforced in order to facilitate disease free processed food and to significantly minimize the public health hazards acquainted with food-borne infectious agents.

\section{Acknowledgement}

This study was supported by Afyon Kocatepe University Research Fund (Project No: 16VF 13).

\section{Conflict of Interest}

The authors declared that there is no conflict of interest.

\section{References}

1. Abdul-Mutalib NA, Abdul-Rashid MF, Mustafa S, et al (2012): Knowledge, attitude and practises regarding food hygiene and sanitation of food handlers in Kuala Pilah, Malaysia. Food Control, 27,289-293.

2. Afifi HA, Abushelaibi AA (2012): Assessment of personal hygiene knowledge, and practices in Al Ain, United Arab Emirates. Food Control, 25, 249-253.

3. Al-Mutairi MF (2011): The incidence of Enterobacteriaceae causing food poisoning in some meat products. Adv J Food Sci Technol, 3, 116-121.

4. Becker K, Heilmann C, Peters G (2014): Coagulasenegative staphylococci. Clin Microbiol Rev, 27, 870-926.

5. Bennett RW, Lancette GA (1992): Staphylococus aureus, 161-164. In: GJ Jackson (Ed), Bacteriological Analytical Manual. Arlington, USA.

6. Bhalla A, Aron DC, Donskey CJ (2007): Staphylococcus aureus intestinal colonization is associated with increased frequency of S. aureus on skin of hospitalized patients. BMC Infec Dis, 7, 1-7.

7. Blood RM, Curtis GDW (1995): Media for 'total' enterobacteriaceae, coliforms and Escherichia coli. Int J Food Microbiol, 26, 93-115.

8. Bloomfield SF, Exner M, Signorelli C, et al (2012): The chain of infection transmission in the home and everyday life settings, and the role of hygiene in reducing the risk of infection. Avaliable at https://www.ifh-homehygiene.org/ sites/default/files/publications/IFHinfectiontransmissionrev iewFINAL.pdf (Accessed March 20, 2019)

9. Dagnew M, Tiruneh M, Moges F, et al (2012): Survey of nasal carriage of Staphylococcus aureus and intestinal parasites among food handlers working at Gondar University, Northwest Ethiopia. BMC Public Health, 12, 837.

10. De Boer E (1998): Update on media for isolation of Enterobacteriaceae from foods. Int J Food Microbiol, 45, 43-53.

11. DeVita MD, Wadhera RK, Steven ML, et al (2007): Assessing the potential of Streptococcus pyogenes and Staphylococcus aureus transfer to foods and customers via asurvey of hands, hand-contact surfaces and food-contact surfaces at foodservice facilities. J Food Service, 18, 76-79.

12. Drzewiecka D (2016): Significance and roles of Proteus spp. bacteria in natural environments. Microb Ecol, 72, 741-758.

13. EuchariaAkanele A, Scholastica MOC, Chukwu MA (2016): Microbiological contamination of food: The mechanisms, impacts and prevention. Int J Scient Technol Res, 5, 65-78.

14. European Food Safety Authority (EFSA) (2010): The community summary report on trends and sources of zoonoses, zoonotic agents and food-borne outbreaks in the European Union in 2008. EFSA Journal, 1, 1410-1496.

15. Felsenstein J (1985): Confidence limits on phylogenies: An approach using the bootstrap. Evolution, 39, 783-791.

16. Foster AP (2012): Staphylococcal skin disease in livestock. Vet Dermatol, 23, 342-363.

17. Greig JD, Todd EC, Bartleson CA, et al (2007): Outbreaks where food workers have been implicated in spread of foodborne disease. Description of the problem, methods, and agents involved. J Food Protect, 70, 17521761.

18. Hall TA (1999): BioEdit: a user-friendly biological sequence alignment editor and analysis program for Windows 95/98/NT. Nucl Acids Symp Ser, 41, 95-98.

19. Kaarina A (2007): Effect of maintenance routines in food processing on production hygiene, 36-38. In: G Wirtanen, S Salovtt (Ed), Microbial Contaminants and Contamination Routes in Food Industry, VTT Espoo, Finland.

20. Kadariya J, Smith TC, Thapaliya D (2014): Staphylococcus aureus and Staphylococcal food-borne disease: an ongoing challenge in public health. BioMed Res Int, Article ID 827965, 1-9.

21. Kalendar R, Lee D, Schulman AH (2009): Fast PCR software for PCR primer and probe design and repeat search. $3 G$ (Bethesda), 3, 1-14.

22. Kaneko KI, Hayashidani H, Ohtomo Y, et al(1999): Bacterial contamination of ready-to-eatfoods and fresh 
products in retail shops and food factories. J Food Protect, 62, 644-649.

23. Lemon KP, Klepac-Ceraj V, Schiffer HK, et al (2010): Comparative analyses of the bacterial microbiota of the human nostril and oropharynx. mBio, 1, 1-9.

24. Mirriam EN, Collins EO, Nicoline FT, et al (2012): Foodborne pathogens recovered from ready-to-eat foods from roadside cafeterias and retail outlets in Alice, Eastern Cape Province, South Africa: public health implications. Int J Environ Res Public Health, 9, 2608-2619.

25. Morot-Bizot SC, Talon R, Leroy S (2004): Development of a multiplex PCR for the identification of Staphylococcus genus and four staphylococcal species isolated from food. $\mathbf{J}$ Appl Microbiol, 97, 1087-1094.

26. NCBI (2019): National Center for Biotechnology Information. Available at http://www.ncbi.nlm.nih. gov/BLAST/. (Accessed March 20, 2019).

27. Nemeghaire S, Argudın MA, Feßler AT, et al (2014): The ecological importance of the Staphylococcus sciuri species group as a reservoir for resistance and virulence genes. Vet Microbiol, 171, 342-356.

28. Normanno G, Firinu A, Virgilio S, et al (2005): Coagulase-positive staphylococci and Staphylococcus aureus in food products marketed in Italy. Int $\mathrm{J}$ Food Microbiol, 98, 73-79.

29. Odu NN, Akano UM (2012): The microbiological assessment of ready-to-eat-food (Shawarma) in Port Harcourt City. Nature and Science, 10, 1-8.

30. Oranusi SU, Oguoma OI, Agusi E (2013): Microbiological quality assessment of foods sold in student's cafeterias. Global Res J Microbiol, 3, 1-7.

31. Piette A,Verschraegen G (2009): Role of coagulasenegative staphylococci in human disease. Vet Microbiol, 134, 45-54.

32. Saitou N, Nei M (1987): The neighbor-joining method: a new method for reconstructing phylogenetic trees. Mol Biol Evol, 4, 406-425.

33. Sani NA, Siow ON (2014): Knowledge, attitudes and practices of food handlers on food safety in food service operations at the Universiti Kebangsaan Malaysia. Food Control, 37, 210-217.
34. Santana NG, Almeida RCC, Ferreira JS, et al (2009): Microbiological quality and safety of meals served to children and adoption of good manufacturing practices in public school catering in Brazil. Food Control, 20, 255-261.

35. Silva Jr, EA (2007): Manual of hygienic control in food service systems. São Paulo, Varela.

36. Soares LS, Almeida RCC, Cerqueira ES, et al (2012): Knowledge, attitudes and practices in food safety and the presence of coagulase-positive staphylococci on hands of food handlers in the schools of Camaçari, Brazil. Food Control, 27, 206-213.

37. Stepanovic S, Vukovicc D, Trajkovic V, et al (2001): Possible virulence factors of Staphylococcus sciuri. FEMS Microbiol Lett, 199, 47-53.

38. Sun YM, Ockerman HW (2005): A review of the needs and current applications of hazard analysis and critical control point (HACCP) system in foodservice areas. Food Control, 16, 325-332.

39. Tambekar DH, Jaiswal VJ, Dhanorkar DV, et al (2008): Identification of microbiological hazards and safety of ready-to-eat food vended in streets of Amravati City, India. J App Biosci, 7, 195-201.

40. Tamura K, Dudley J, Nei M, et al (2007): Molecular evolutionary genetics analysis (MEGA) software version 4.0, Mol Biol Evol, 24, 1596-1599.

41. Tamura K, Nei M, Kumar S (2004): Prospects for inferring very large phylogenies by using the neighborjoining method. PNAS, 101:11030-11035/.

42. Valero A, Rodríguez MY, Posada-Izquierdo GD, et al (2016): Risk factors influencing microbial contamination in food service centers, 28-58. In: HA Makun (Ed), Significance, prevention and control of food related diseases. Intech Open press, Croatia.

43. Wang Y, Zhang S, Yu J, et al (2010): An outbreak of Proteus mirabilis food poisoning associated with eating stewed pork balls in brown sauce, Beijing. Food Control, 21, 302-305.

44. Wirtanen G, Storgards E, Mattila-Sandholm T (2003): Biofilms, 484-489. In: B Caballero, L Trugo, P Finglas (Ed), Encyclopedia of Food Sciences and Nutrition. Academic Press, London. 